\title{
Inhibition of MMP-2 and MMP-9 activities by solvent-partitioned Sargassum horneri extracts
}

\author{
Fatih Karadeniz ${ }^{1}$, Seul-Gi Lee ${ }^{2}$, Jung Hwan Oh², Jung-Ae Kim²,3 and Chang-Suk Kong ${ }^{2,3^{*}}$ (D)
}

\begin{abstract}
Background: Matrix metalloproteinases (MMPs) are linked with several complications such as metastasis of cancer progression, oxidative stress, and hepatic fibrosis. Brown seaweeds are being extensively studied for their bioactive molecule content against cancer progression. In this context, Sargassum horneri was reported to possess various bioactivities including antiviral, antimicrobial, and anti-inflammatory partly due to its phenolic compound content.

Methods: In this study, potential of S. horneri was evaluated through anti-MMP effect in HT1080 fibrosarcoma cells. S. horneri crude extract was fractionated with organic solvents, namely, water $\left(\mathrm{H}_{2} \mathrm{O}\right), n$-buthanol $(n-\mathrm{BuOH}), 85 \%$ aqueous methanol ( $85 \%$ aq. $\mathrm{MeOH}$ ), and $n$-hexane. The non-toxicity of fraction samples (Sargassum horneri solventpartitioned extracts (SHEs)) was confirmed by cell-viability assay. SHEs were tested for their ability to inhibit MMP enzymatic activity through gelatin digestion evaluation and cell migration assay. Expressions of MMP-2 and MMP-9 and tissue inhibitors of MMP (TIMPs) were evaluated by reverse transcription and Western blotting.
\end{abstract}

Results: All fractions inhibited the enzymatic activities of MMP-2 and MMP-9 according to gelatin zymography. Except $\mathrm{H}_{2} \mathrm{O}$ fraction, fractions hindered the cell migration significantly. All tested fractions suppressed both mRNA and protein levels of MMP-2, MMP-9, TIMP-1, and TIMP-2.

Conclusion: Overall, current results suggested that $S$. horneri has potential to be a good source for anti-MMP agents, and further investigations are underway for better understanding of the action mechanism and isolation and elucidation of the bioactive molecules.

Keywords: Brown algae, MMP, Sargassum horneri, TIMP

\section{Background}

Matrix metalloproteinases are hailed as crucial enzymes that have important roles in cancer progression and several tumor-related complications (Jones and Walker 1997). Due to their nature, matrix metalloproteinases (MMPs) are pivotal in cell proliferation and migration which are closely linked with invasive tumor cells and onset of malignant tumor growth (Moss et al. 2012). In addition, MMPs which are zinc-dependent endopeptidases responsible for extracellular matrix degradation

\footnotetext{
* Correspondence: cskong@silla.ac.kr

${ }^{2}$ Department of Food and Nutrition, College of Medical and Life Sciences, Silla University, Baegyang-dero 700beon-gil 140, Sasang-gu, Busan 46958, Republic of Korea

${ }^{3}$ Marine Biotechnology Center for Pharmaceuticals and Foods, Silla University, Baegyang-dero 700beon-gil 140, Sasang-gu, Busan 46958, Republic of Korea
} Full list of author information is available at the end of the article are known to be involved heavily in various disorders including inflammatory response, cardiovascular diseases, arthritis, and most types of cancer (Bauvois 2012; Egeblad and Werb 2002; Overall and López-Otín 2002). Different classifications of MMPs occur depending on the tissues they are found, their functions, and their expression patterns. There are several types of extracellular matrixrelated enzymes defined in human cellular mechanisms. Among them, MMP-2 (72 kDa) and MMP-9 (92 kDa) are found to regulate tumor invasion and metastasis. Researches in malignant tumors reported the overexpression and enhanced activity of both of these MMPs (Ibañez and Cifuentes 2013). Enhanced metastasis is evidently linked with enhanced MMP-2 and MMP-9 expressions. Therefore, studies on hindering or inhibiting the expression or activity of MMPs gained interest and put several MMP 
types including MMP-2 and MMP-9 into spotlight as therapeutic targets. MMPs are regulated by tissue inhibitor of MMP (TIMP) through a negative feedback mechanism acted on activation of MMP enzymes. TIMP expression inhibits all types of MMPs other than gelatinases. Normal regulation mechanism of TIMPs ought to be deteriorated and further facilitate the enhancement of MMP expression in malignant tumors ( $\mathrm{Yu}$ and $\mathrm{Gu} 2015$ ).

Brown macroalgae have been of much interest due to their known ability to withstand different marine environments by producing various secondary metabolites. Some brown algae species already have been reported to possess numerous health beneficial effects (Holdt and Kraan 2011; Matanjun et al. 2009; Patarra et al. 2011). Low content in harmful lipids and high content in polysaccharides, unsaturated fatty acids, vitamins, and minerals enable marine algae to be promoted as a nutritious source for healthy diets (Plaza et al. 2010). Sargassum horneri is a common species of brown macroalgae that grows on the coastal sea of Korea and Japan. Although it has been a part of a diet in limited areas of Japan, it could not enter the market as a processed product until recently. Literature contains little information about its chemical composition and nutritional aspects (de la Mare et al. 2012; Thomas and Kim 2011). Extracts from S. horneri were observed to stimulate the formation of bone tissue and to prevent bone loss (Jiao et al. 2009). In addition, chromene isolated from S. horneri was reported to possess a protective effect against UV-A-induced damage in skin dermal fibroblasts (Reuter et al. 2010). In this context, as a part of ongoing research to develop antitumor compounds, especially MMP inhibitors from natural origin, current study aims to present understanding on the potential of $S$. horneri as a source for natural products that can act on MMP activity. In this manner, solvent-partitioned fractions of $S$. horneri extract were screened for their effects on MMP-2 and MMP-9 activity and expression.

\section{Methods}

\section{Plant materials and fractionation}

S. horneri was purchased from Parajeju (Jeju, Korea) in 2013. The sample $(1000 \mathrm{~g})$ was air-dried outdoors under shade, ground to powder using a blender (NFM-3561SN, NUC Co. Ltd., Seoul, Korea) at high-speed grinding setting, and extracted in a 5-l Erlenmeyer flask with EtOH (3 l) for three times. The collected extracts were concentrated under reduced pressure with a rotary evaporator $(80 \mathrm{mbar}$, $50{ }^{\circ} \mathrm{C}$ ) (RV 10 Series, IKA, Wilmington, NC, USA).

The crude extract (128 g) was suspended in between $\mathrm{CH}_{2} \mathrm{Cl}_{2}$ and water. Later, the $\mathrm{CH}_{2} \mathrm{Cl}_{2}$ layer was separated by $85 \%$ aqueous $\mathrm{MeOH}$ and $n$-hexane. Next, the water layer was partitioned with $n-\mathrm{BuOH}$ and $\mathrm{H}_{2} \mathrm{O}$, respectively. Overall, the solvent partition yielded the $n$-hexane (0.73 g), $85 \%$ aq. $\mathrm{MeOH}$ (4.05 g), $n-\mathrm{BuOH}$ (1.08 g), and $\mathrm{H}_{2} \mathrm{O}(71.32 \mathrm{~g})$ fractions.

\section{Cell culture and cell viability determination}

HT1080 human fibrosarcoma cells were cultured in T-75 culture flasks (Nunc, Roskilde, Denmark) in an incubator with $37^{\circ} \mathrm{C}$ and $5 \% \mathrm{CO}_{2}$ atmosphere with Dulbecco's modified Eagle's medium (DMEM; Gibco-BRL, Gaithersburg, MD, USA) containing 10\% fetal bovine serum (FBS), $2 \mathrm{mM}$ glutamine, and $100 \mu \mathrm{g} / \mathrm{ml}$ penicillin-streptomycin (Gibco-BRL, Gaithersburg, MD, USA). The medium was changed every 3 days.

For cell viability assessment, cells were cultured in 96well plates at a $5 \times 10^{3}$ cells/well density. Following a 24-h incubation, cell culture medium was removed and the cells were washed with fresh medium and prior to treatment with the medium with or without $S$. horneri samples. After incubation for $48 \mathrm{~h}$, cells were re-washed with fresh medium and $100 \mu \mathrm{l}$ of 3-(4,5-dimethylthiazol-2-yl)-2,5-diphenyltetrazolium bromide (MTT) solution $(1 \mathrm{mg} / \mathrm{ml})$ was introduced to the wells, followed by a 4-h incubation. Finally, $100 \mu \mathrm{l}$ of dimethyl sulfoxide (DMSO) was used for each well in order to solubilize the formazan crystals prior to absorbance measurement at $540 \mathrm{~nm}$ using a GENios microplate reader (Tecan Austria GmbH, Grödig, Austria). Cell viability was defined by the absorbance value as a way to indicate the amount of MTT converted into formazan crystal. Viability of cells was determined as a percentage in comparison to the untreated control wells against sample-treated wells, and dose response curves were established.

\section{Cell migration assay}

Cells were grown on a 12 -well culture dish to $90 \%$ confluence followed by forming an injury line with a width of $2 \mathrm{~mm}$ from scraping vertically across the cell layer with a sterile scraper. Floating cell debris was washed away with phosphate-buffered saline (PBS), and cell medium was changed to serum-free medium. Cells were treated with $50 \mu \mathrm{g} / \mathrm{ml}$ Sargassum horneri solventpartitioned extracts (SHEs). Cell migration was observed under an inverted microscope (Nikon Eclipse TS100, Nikon Instruments, Melville, NY, USA), and photographs were taken at incubation starting time and after $24 \mathrm{~h}$ of incubation.

\section{MMP enzymatic activity determination by gelatin \\ zymography}

Enzymatic activities of MMP-2 and MMP-9 from HT1080 cells that were treated with or without samples were detected by gelatin zymography. HT1080 cells were cultured in 24-well plates with a density of $2 \times 10^{5}$ cells/well in a serum-free medium and were introduced to different concentrations of sample for $1 \mathrm{~h}$. Phorbol 12-myristate 13-acetate (PMA; $10 \mathrm{ng} / \mathrm{ml}$ ) was used to enhance the MMP expression, and cells were further incubated for $24 \mathrm{~h}$ after PMA treatment. Total protein contents of the 
cells were normalized using Bradford protein determination method. Next, cell culture medium was subjected to substrate-gel electrophoresis. Conditioned cell culture medium with the same amount of protein was transferred on $10 \%$ polyacrylamide gels under non-reducing conditions containing $1.5 \mathrm{mg} / \mathrm{ml}$ gelatin. Polyacrylamide gels were then washed with $50 \mathrm{mM}$ Tris- $\mathrm{HCl}(\mathrm{pH}$ 7.5) containing $2.5 \%$ Triton $\mathrm{X}-100$ to remove any remaining sodium dodecyl sulfate. After the washing process, gels were incubated for $48 \mathrm{~h}$ at $37{ }^{\circ} \mathrm{C}$ in developing buffer (10 $\mathrm{mM} \mathrm{CaCl}_{2}, 50 \mathrm{mM}$ Tris- $\mathrm{HCl}, 150 \mathrm{mM} \mathrm{NaCl}$ ) in order to facilitate gelatin digestion. Areas of gelatin hydrolyzation by MMP were observed as clear zones against blue background of Coomassie Blue staining under a CAS400SM Davinch-Chemi imager ${ }^{\text {TM }}$ (Davinch-K, Seoul, Korea).

\section{RNA isolation and reverse transcription-polymerase chain reaction (RT-PCR) analysis}

Total cellular RNA was extracted by TRIzol reagent (Thermo Fisher Scientific, Waltham, MA, USA) from sample-treated and control wells. Any changes in the concentration of mRNA for MMP-2 and MMP-9 were determined by RT-PCR. Briefly, $2 \mu \mathrm{g}$ of total RNA from cells was converted to single-stranded cDNA using a reverse transcription system (Promega, Madison, WI, USA). The target cDNA was amplified using the following primers: forward $5^{\prime}$-TGA-AGG-TCG-GTG-TGA-ACG-GA-3' and reverse 5'-CAT-GTA-GCC-ATG-AGG-TCC-ACC-AC-3' for MMP-2; forward 5'-CAC-TGT-CCA-CCC-CTC-AG A-GC-3' and reverse $5^{\prime}$-CAC-TTG-TCG-GCG-ATA-AG G-3' for MMP-9; forward 5'-AAT-TCC-GAC-CTC-GTCATC-AG-3' and reverse 5'-TGC-AGT-TTT-CCA-GCAATG-AG-3' for TIMP-1; forward 5'-TGA-TCC-ACA-CA C-GTT-GGT-CT-3' and reverse 5'-TTT-GAG-TTG-CT T-GCA-GGA-TG-3' for TIMP-2; and forward 5'-GCC-A CC-CAG-AAG-ACT-GTG-GAT-3' and reverse 5' ${ }^{\prime}$-TGGTCC-AGG-GTT-TCT-TAC-TCC-3' for $\beta$-actin. Cycles were $95{ }^{\circ} \mathrm{C}$ for $45 \mathrm{~s}, 60{ }^{\circ} \mathrm{C}$ for $1 \mathrm{~min}$, and $72{ }^{\circ} \mathrm{C}$ for $45 \mathrm{~s}$ for amplification. Following the completion of 30 cycles, the final products were separated by electrophoresis on $1.5 \%$ agarose gel for $30 \mathrm{~min}$ at $100 \mathrm{~V}$. Gel staining was carried out with $1 \mathrm{mg} / \mathrm{ml} \mathrm{EtBr}$, and visualization by UV light using AlphaEase ${ }^{\bullet}$ gel image analysis software was finalized with the assay (Alpha Innotech, San Leandro, CA, USA).

\section{Western blot analysis}

Immunoblotting was performed according to common standard procedures. To explain briefly, HT1080 cells were agitated in RIPA lysis buffer (Sigma-Aldrich Corp., St. Louis, USA) at $4{ }^{\circ} \mathrm{C}$ for $30 \mathrm{~min}$. Cell lysates $(35 \mu \mathrm{g})$ were then subjected to separation using 10\% SDSpolyacrylamide gel electrophoresis and transferred onto a polyvinylidene fluoride membrane (Amersham Pharmacia Biosciences., England, UK), blocking with
5\% skim milk and hybridization with primary antibodies (diluted 1:1000). Membranes were then incubated with horseradish-peroxidase-conjugated secondary antibodies at room temperature. Immunoreactive proteins were detected using an electrochemiluminescence kit (Amersham Pharmacia Biosciences, England, UK) according to the manufacturer's instructions. Protein bands were observed using a CAS-400SM Davinch-Chemi imager ${ }^{\text {rux }}$ (Davinch-K, Seoul, Korea).

\section{Statistical analysis}

The data were presented as a mean of three different experiments \pm SD. Differences between the calculated means of the each individual group were determined by one-way ANOVA coupled with Duncan's multiple range tests. Any difference was considered statistically significant at $p<0.05$. The statistical software SAS v9.1 (SAS Institute Inc., Cary, NC, USA) was used for analyses.

\section{Results and discussion}

Particular important pathways for metastasis, oxidative stress, and fibrosis are known to be influenced by the activities of MMPs (Holdt and Kraan 2011; Plaza et al. 2010). Therefore, MMP inhibitors steadily gain high interest from various research and development studies of pharma and nutraceutical approaches. Recently, natural sources for MMP-inhibiting substances are being intensively studied, and in this context, marine organisms hold a great deal of potential being present in a unique and challenging environment. Various organisms, especially marine plants, and metabolites have been identified as potential MMP inhibitors, and possible mechanisms of action for isolated compounds have been suggested (de la Mare et al. 2012; Thomas and Kim 2011). In order to provide valuable insights on that matter, $S$. horneri was studied to evaluate its MMP-inhibition efficiency. In order to help the future utilization through isolated and elucidated bioactive substances, crude extract of S. horneri was fractioned with organic solvents and solvent-partitioned extracts were tested separately.

First, the solvent-partitioned extract (SHE) samples were tested for its cytotoxic presence in human fibrosarcoma cell line HT1080 for $48 \mathrm{~h}$ at two different concentrations (5 and $50 \mu \mathrm{g} / \mathrm{ml}$ ) (Fig. 1). The cytotoxicity test revealed that these concentrations were not significantly toxic and any observed inhibition of MMP-2 and MMP9 activity was not caused by any cytotoxic influence.

SHEs were analyzed for their possible activity to inhibit MMP-2 and MMP-9 enzymes following a PMA stimulation. Gelatinolytic activity of MMP-2 and MMP-9 secreted from fibrosarcoma cell line HT1080 was evaluated with gelatin zymography which was carried out with PMAstimulated conditioned medium of SHE-treated cells (Fig. 2). Introduction of PMA (10 $\mathrm{ng} / \mathrm{ml})$ to cells resulted 


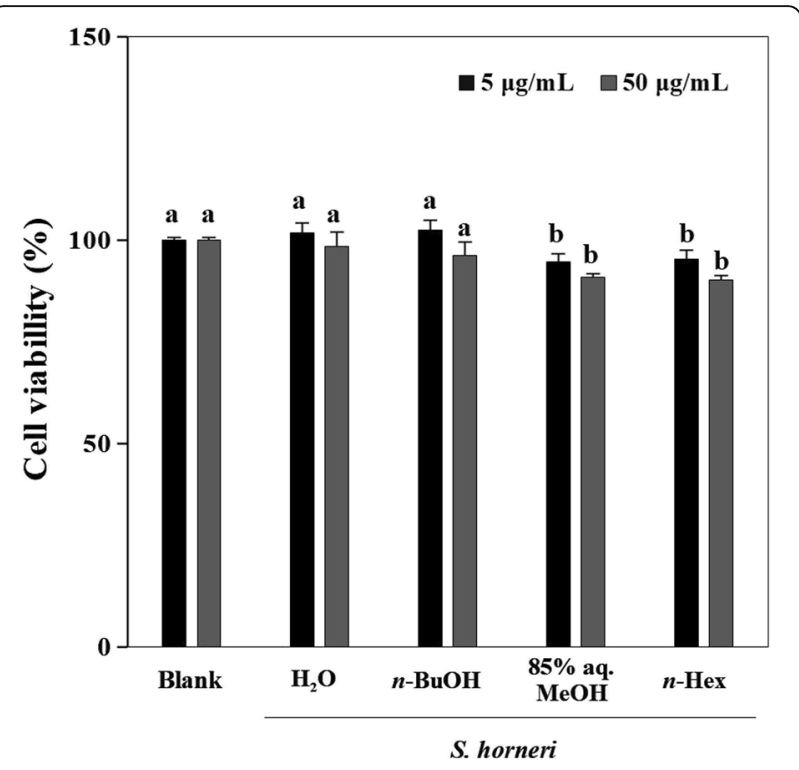

Fig. 1 Effect of solvent-partitioned S. horneri extracts (SHEs) on cell viability of HT1080 human fibrosarcoma cells. The cells were treated with different concentrations of SHEs ( 5 and $50 \mu \mathrm{g} / \mathrm{ml}$ ) and incubated for $48 \mathrm{~h}$. The cytotoxicity was determined by MTT assay. Values are mean \pm SD $(n=3)$. Means with the different letters are significantly different $(P<0.05)$ by Duncan's multiple range test in enhanced activation of MMP-2 and MMP-9; hence, gelatinolytic activity in gelatin zymography was elevated. Among tested SHEs, $85 \%$ aq. $\mathrm{MeOH}$ decreased both MMP-2 and MMP-9 activity in a dose-dependent relevantly higher manner. The remaining SHEs were observed to inhibit both MMP activity in an order of $n$ - $\mathrm{BuOH}, n$-hexane, and $\mathrm{H}_{2} \mathrm{O}$, respective to their efficiency. In Fig. 2, the MMP-2 activity was depicted as a percentage to that of activation of MMP-2 from proMMP-2. Data showed that the $n-\mathrm{BuOH}$ and $\mathrm{H}_{2} \mathrm{O}$ SHEs notably increased the MMP-9 activity while showing decreased MMP-2 activity. This can be linked to the regulatory dynamic between MMP-2 and MMP-9. In general, MMP inhibitors are usually selective; for example, an inhibitor for MMP-2 can be ineffective against MMP-9 (Benjamin and Khalil 2012). Additionally, suppressed MMP-2 production was suggested to result in increased MMP-9-mediated gelatinase activity (Kato et al. 2015) which might explain the inconsistencies among the tested samples with regard to their inhibition and/or enhancing effect towards MMPs. Inhibition of MMP activities indicated that the SHEs possess bioactive compounds that could have effects on the extracellular activity of MMP-2 and MMP-9.

With the possible MMP inhibitory presence of SHEs, effect on cell migration was observed using cell migration assay on HT1080 human fibrosarcoma cells. Cells without any treatment showed signs of migration after a 24-h incubation while SHE-treated cells had hindered

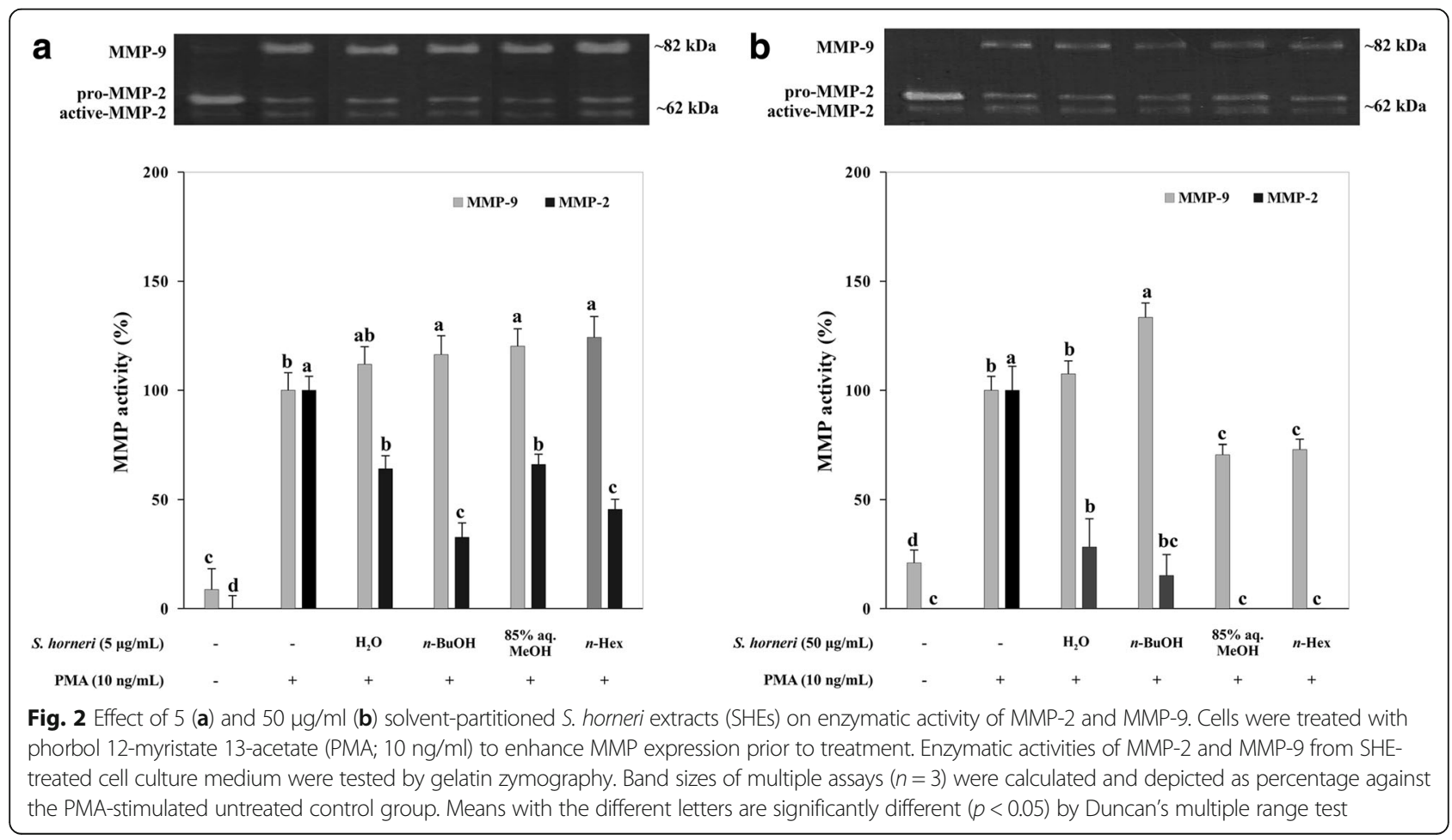


migration patterns (Fig. 3). Treatment with $50 \mu \mathrm{g} / \mathrm{ml}$ SHE inhibited the migration ability of tumor cells significantly, indicating a possible inhibition of MMPs which are important enzymes for the invasive nature and migration of tumor cells (Thomas and Kim 2011). SHEs were ordered as $85 \%$ aq. $\mathrm{MeOH}, n$-hexane, $n$ - $\mathrm{BuOH}$, and $\mathrm{H}_{2} \mathrm{O}$ according to their level of cell migration inhibition.

Further, RNA and total protein levels of MMP-2 and MMP-9 were determined by RT-PCR and immunoblotting with the levels of TIMP-1 and TIMP-2. TIMPs are known inhibitors of MMPs that are also reported to elevate the activity of MMP-2 in some presented situations (Jiao et al. 2009). RT-PCR and immunoblotting results suggested the treatment with SHEs was able to hinder the expression of MMP-2 and MMP-9 in terms of both mRNA (Fig. 4a) and protein levels (Fig. 4b). The presence of TIMPs is considered to imply for inhibited MMP activity as a part of cellular response for extracellular stimuli (Reuter et al. 2010). Hence, the PMA stimulation caused TIMP levels to decrease and MMP expression to increase (Fig. 4). However, treatment with SHE was observed to produce mixed results regarding the effect on the TIMP levels following the PMA stimuli. Expected results were to inhibit MMP expression while enhancing TIMP expression in order to regulate the extracellular matrix degradation. In these terms, only $85 \%$ aq. $\mathrm{MeOH}$ and $n$-hexane were able to regulate the MMP-2, MMP-9, TIMP-1, and TIMP-2 levels. On the other hand, protein levels of MMP-2 and MMP-9 were slightly elevated after $\mathrm{H}_{2} \mathrm{O}$ and $n-\mathrm{BuOH}$ SHE treatment with elevated TIMP-1 and TIMP-2 levels while mRNA levels did not depict any significant changes for all tested SHE samples. In addition, as mentioned earlier, elevated levels of TIMP-2 have caused an increase in MMP-2 protein levels in terms of $n$-hexane SHE treatment. Nonetheless, SHEs were shown to have an effect on both activity and expression of MMP pathways but with suggested different mechanisms of action. In cases of $\mathrm{H}_{2} \mathrm{O}$ and $n-\mathrm{BuOH}$ samples, a possible intervention for the activation of MMP-2 and MMP-9 enzymes was suggested following the elevated protein levels of MMPs which would explain the inhibited enzyme activity and elevated protein levels. In terms of the remaining SHEs, a mechanism where TIMP-linked regulation of MMP activity as well as direct bonds between substances in SHE and enzyme results in inhibition of MMP-2 and MMP-9. In other terms, certain discrepancies among the activities of samples in different assays were suggested to be the outcome of different chemical compositions and more than one bioactive compound presence. While most active SHEs were able to interact with the MMP enzymatic activity to show their effect, least active SHEs were suggested to interact with the intracellular pathways of expression and activation of MMPs. Accordingly, as the most active of all samples and all results considered, $85 \%$ aq. $\mathrm{MeOH}$ SHE was observed to show its efficiency against MMP activity tested by gelatin zymography and cell migration. On the other hand, while $n-\mathrm{BuOH}$ SHE was ineffective in hindering cell migration and inhibiting MMP gelatinase activity, it was able to suppress the MMP expression while enhancing the mRNA levels of TIMPs. The $\mathrm{MeOH}$ fractions which were suggested to be a phenol-rich extract (Seo et al. 2004; Shipeng et al. 2015), therefore, were suggested to inhibit the enzymatic activity of MMPs through direct interaction. The $n-\mathrm{BuOH}$ fractions which were reported to be rich in chromones and coumarins (Kim et al. 2015), however, were able to regulate the intracellular pathways of MMP expression while having little to no effect on enzymatic activity.

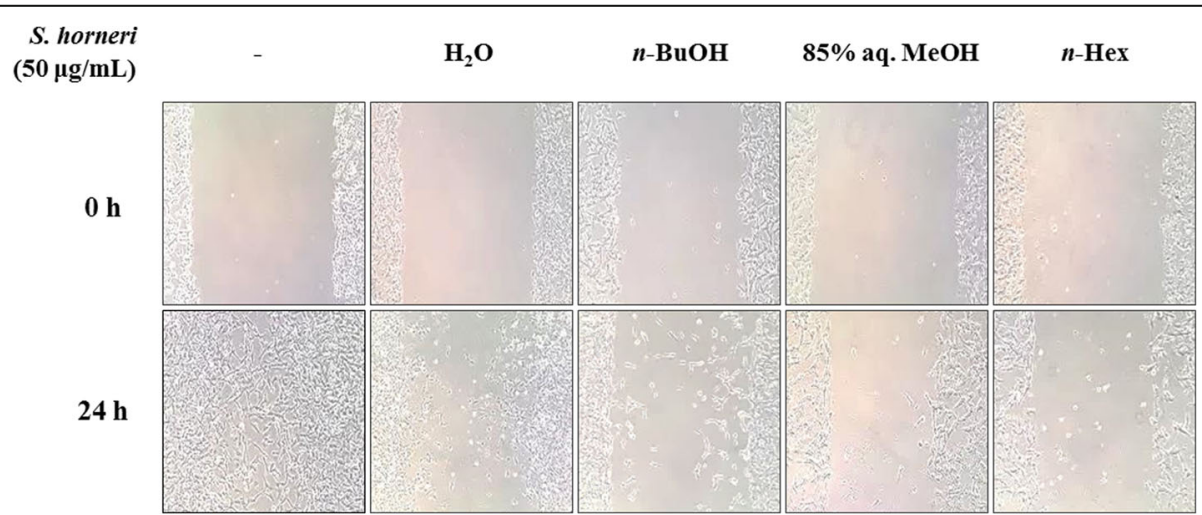

Fig. 3 Effect of solvent-partitioned S. horneri extracts (SHEs) on migration ability of PMA-stimulated HT1080 human fibrosarcoma cells. Cells were injured with a line of 2-mm width and treated with $50 \mu \mathrm{g} / \mathrm{ml}$ SHEs $(10,50$, and $100 \mu \mathrm{g} / \mathrm{ml})$. Cell images were taken at the time of treatment and end of a $24 \mathrm{~h}$ incubation in order to observe migration 


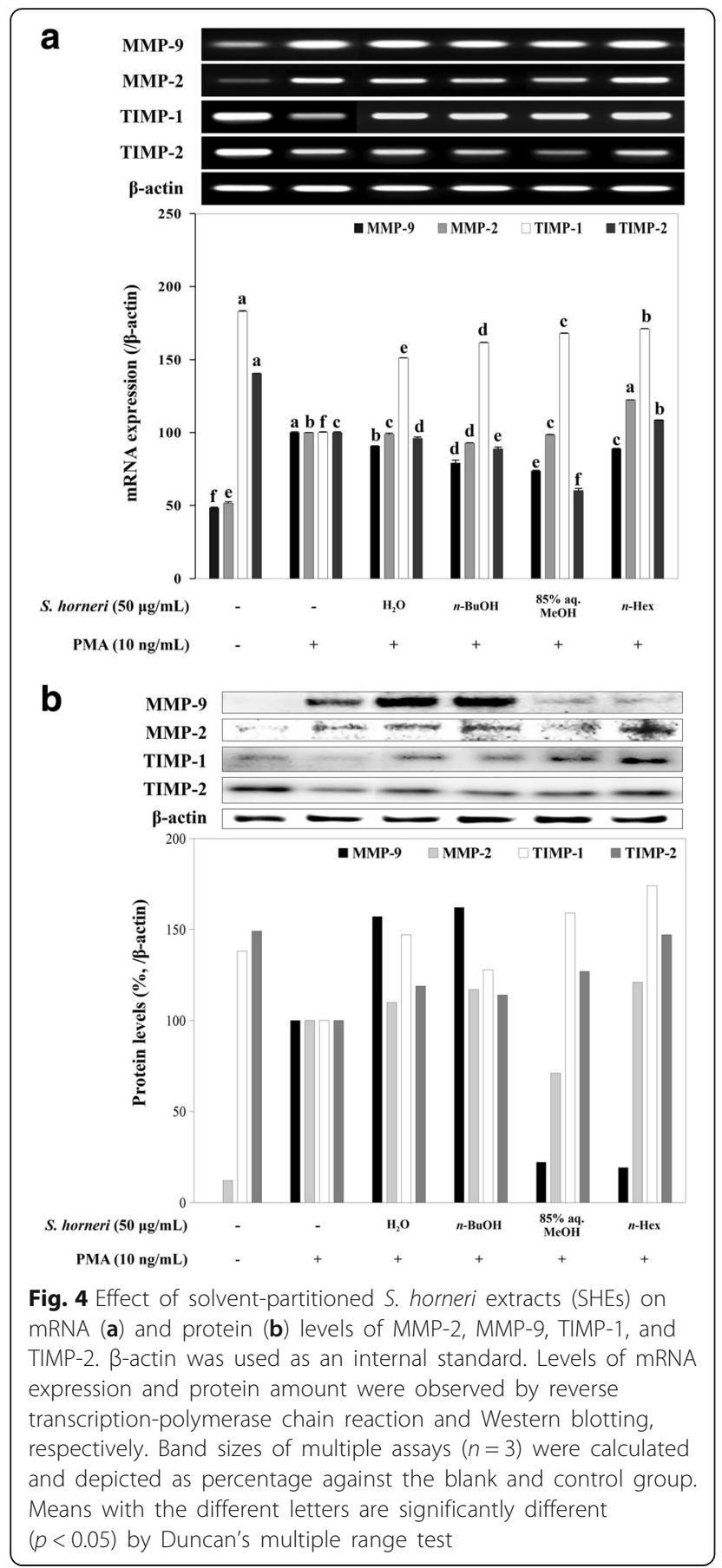

\section{Conclusions}

Possible chemical composition of the $85 \%$ aq. $\mathrm{MeOH}$ SHE, the most active sample according to current results, was suggested to be formed mostly with phenol-based compounds which are common bioactive substances of brown algae with health beneficial effects (Bhatnagar and Kim 2010) while $\mathrm{H}_{2} \mathrm{O}$ and $n$-BuOH SHE possibly contain more glycol-based compounds. Some MMP-inhibiting polysaccharides ( $\mathrm{Tu}$ et al. 2008) and benzopyran derivates from different sources were already isolated and reported while similar compounds were also found in S. horneri with different bioactivities. Nevertheless, current results indicated that $S$. horneri is a source for MMP inhibitors that might lead to future development of anti-tumor compounds. On the other hand, detailed evaluation of S. horneri and its constituents will also provide valuable insights for its utilization as functional food, and future studies on its detail action mechanism are urged for a better understanding of its potential. In the current state, S. horneri was suggested as a potential nutraceutical due to its potential anti-MMP effect.

\section{Abbreviations}

MMP: Matrix metalloproteinase; MTT: 3-(4,5-Dimethylthiazol-2-yl)-2,5diphenyltetrazolium bromide; PMA: Phorbol 12-myristate 13-acetate;

SHE: Sargassum horneri solvent-partitioned extract; TIMP: Tissue inhibitor of matrix metalloproteinase

\section{Funding}

This work was supported by the Basic Science Research Program through the National Research Foundation of Korea (NRF) funded by the Ministry of Education, Science and Technology [grant number NRF-2014R1A1A2059310].

Availability of data and materials

All datasets and materials are available from the corresponding author on a reasonable request.

\section{Authors' contributions}

FK and SGL carried out the experiments. JAK, and CSK conceived the idea and designed the experiments. FK, JHO and JAK participated to write the manuscript and interpreted the data. JHO performed the necessary revisions and updates on the manuscript. All authors read and approved the final manuscript.

Ethics approval and consent to participate

Not applicable.

\section{Consent for publication}

Not applicable.

\section{Competing interests}

The authors declare that they have no competing interests.

\section{Publisher's Note}

Springer Nature remains neutral with regard to jurisdictional claims in published maps and institutional affiliations.

\section{Author details}

${ }^{1}$ Department of Organic Material Science and Engineering, Pusan National University, Busandaehak-ro 63beon-gil 2, Geumjeong-gu, Busan 46241, Republic of Korea. ${ }^{2}$ Department of Food and Nutrition, College of Medical and Life Sciences, Silla University, Baegyang-dero 700beon-gil 140, Sasang-gu, Busan 46958, Republic of Korea. ${ }^{3}$ Marine Biotechnology Center for Pharmaceuticals and Foods, Silla University, Baegyang-dero 700beon-gil 140, Sasang-gu, Busan 46958, Republic of Korea.

Received: 18 January 2018 Accepted: 12 March 2018

Published online: 18 June 2018

\section{References}

Bauvois B. New facets of matrix metalloproteinases MMP-2 and MMP-9 as cell surface transducers: outside-in signaling and relationship to tumor progression. Biochim Biophys Acta Rev Cancer. 2012;1825:29-36.

Benjamin MM, Khalil RA. Matrix metalloproteinase inhibitors as investigative tools in the pathogenesis and management of vascular disease. EXS. 2012;103: 209-79. 
Bhatnagar I, Kim SK. Marine antitumor drugs: status, shortfalls and strategies. Mar Drugs. 2010;8:2702-20.

de la Mare JA, Lawson JC, Chiwakata MT, Beukes DR, Edkins AL, Blatch GL. Quinones and halogenated monoterpenes of algal origin show antiproliferative effects against breast cancer cells in vitro. Investig New Drugs. 2012;30:2187-200.

Egeblad M, Werb Z. New functions for the matrix metalloproteinases in cancer progression. Nat Rev Cancer. 2002;2:161-74.

Holdt SL, Kraan S. Bioactive compounds in seaweed: functional food applications and legislation. J Appl Phycol. 2011;23:543-97.

Ibañez E, Cifuentes A. Benefits of using algae as natural sources of functional ingredients. J Sci Food Agric. 2013;93:703-9.

Jiao J, Friedman SL, Aloman C. Hepatic fibrosis. Curr Opin Gastroenterol. 2009;25: 223-9.

Jones JL, Walker RA. Control of matrix metalloproteinase activity in cancer. J Pathol. 1997;183:377-9.

Kato H, Duarte S, Liu D, Busuttil RW, Coito AJ. Matrix metalloproteinase-2 (MMP-2) gene deletion enhances MMP-9 activity, impairs PARP-1 degradation, and exacerbates hepatic ischemia and reperfusion injury in mice. PLoS One. 2015; 10(9):e0137642.

Kim YA, Kong CS, Park HH, Lee E, Jang MS, Nam KH, Seo Y. Anti-inflammatory activity of heterocarpin from the salt marsh plant Corydalis heterocarpa in LPS-induced RAW 264.7 macrophage cells. Molecules. 2015;20:14474-86.

Matanjun P, Mohamed S, Mustapha NM, Muhammad K. Nutrient content of tropical edible seaweeds, Eucheuma cottonii, Caulerpa lentillifera and Sargassum polycystum. J Appl Phycol. 2009;21:75-80.

Moss LAS, Jensen-Taubman S, Stetler-Stevenson WG. Matrix metalloproteinases: changing roles in tumor progression and metastasis. Am J Pathol. 2012;181: 1895-9.

Overall CM, López-Otín C. Strategies for MMP inhibition in cancer: innovations for the post-trial era. Nat Rev Cancer. 2002;2:657-72.

Patarra RF, Paiva L, Neto Al, Lima E, Baptista J. Nutritional value of selected macroalgae. J Appl Phycol. 2011;23:205-8.

Plaza M, Santoyo S, Jaime L, Reina GGB, Herrero M, Señoráns FJ. Screening for bioactive compounds from algae. J Pharm Biomed Anal. 2010;51:450-5.

Reuter S, Gupta SC, Chaturvedi MM, Aggarwal BB. Oxidative stress, inflammation, and cancer: how are they linked? Free Radic Biol Med. 2010;49:1603-16.

Seo Y, Lee HJ, Park KE, Kim YA, Ahn JW, Yoo JS, Lee BJ. Peroxynitrite-scavenging constituents from the brown alga Sargassum thunbergii. Biotechnol Bioprocess Eng. 2004;9:212-6.

Shipeng Y, Woo HC, Choi JH, Park YB, Chun BS. Measurement of antioxidant activities and phenolic and flavonoid contents of the brown seaweed Sargassum horneri: comparison of supercritical $\mathrm{CO}_{2}$ and various solvent extractions. Fish Aquat Sci. 2015;18:123-30.

Thomas NV, Kim SK. Potential pharmacological applications of polyphenolic derivatives from marine brown algae. Environ Toxicol Pharmacol. 2011;32: 325-35.

Tu G, Xu W, Huang H, Li S. Progress in the development of matrix metalloproteinase inhibitors. Curr Med Chem. 2008;15:1388-95.

Yu P, Gu H. Bioactive substances from marine fishes, shrimps and algae and their functions: present and future. Crit Rev Food Sci Nutr. 2015;55:1114-36.

\section{Submit your next manuscript to BioMed Central and we will help you at every step:}

- We accept pre-submission inquiries

- Our selector tool helps you to find the most relevant journal

- We provide round the clock customer support

- Convenient online submission

- Thorough peer review

- Inclusion in PubMed and all major indexing services

- Maximum visibility for your research

Submit your manuscript at www.biomedcentral.com/submit 